\title{
مسالة الأحوال
}

بيز ملدرسة القاضي عبد الجباروملدرسة أبي الحسيز البصري

الباحث / خافا مدهد متوليا نصال

إشرافا

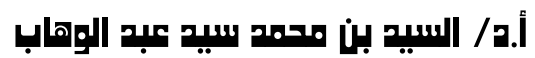

نقد أبو الحسين البصري لنظرية الأحوال :-

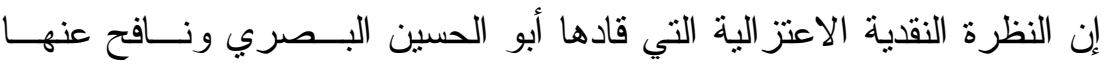

تلامذته من بعده كان لها كبير أثز على صياغة دذهب الاعتز ال عند المتأخرين ســـواء

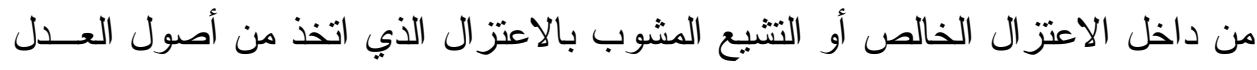
و التوحيد منهجا اعتقاديا مع الخلاف الحاصل في أمور الإمامة وغير ها أو حتى الـسني

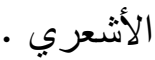

ولكن إذا كان حديثنا عن نقد مذهب الاعتزال عند المتأخرين فلا ينبخي إغفــال أمر بالغ في الأهمية وهو أثز الجبائيين في نيار المتأخرين لأنهما قطبا الرحى وحولهين

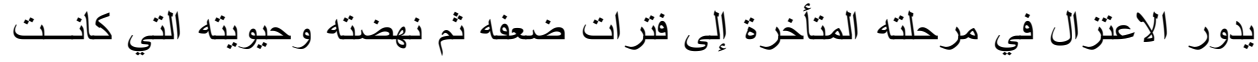

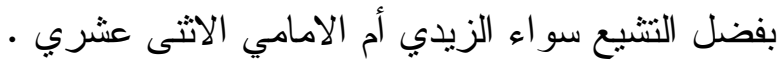

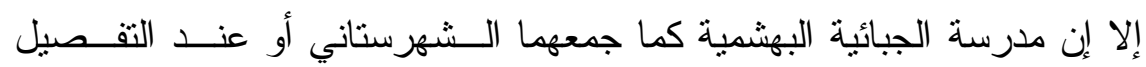

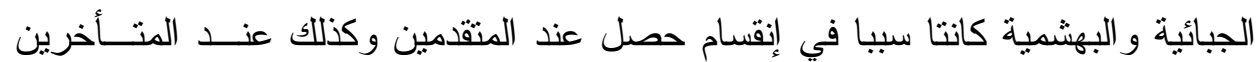

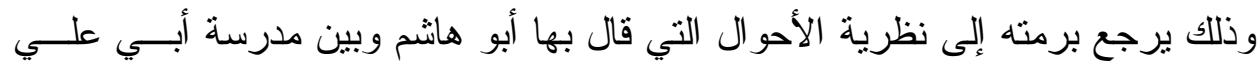

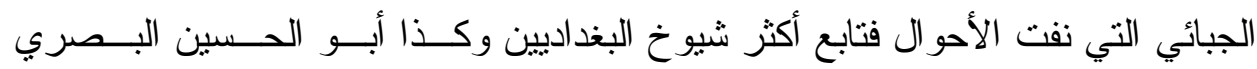

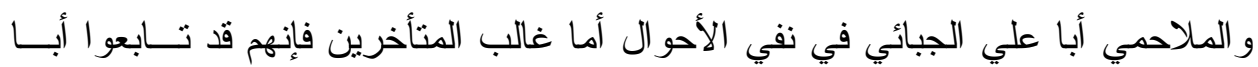

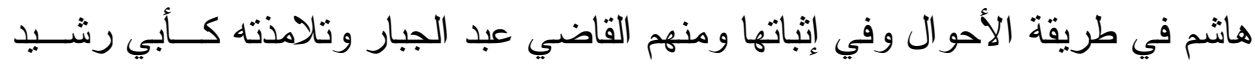
و ابن متوية وغالب البهاثمة على العموم

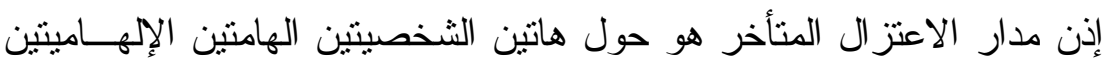
فلهما بالغ الأثر في تشكل الفكر الاعتز الي المتأخر . 
و هذه تقدمة هامة في تصور الخلاف الحاصل عند المتاخرين و الــدوران فـي فللك تلك المقدمة لا ينفك عنه المبحث فتبلور الأفكار الاعتز الية عند المتأخرين لم يفارق

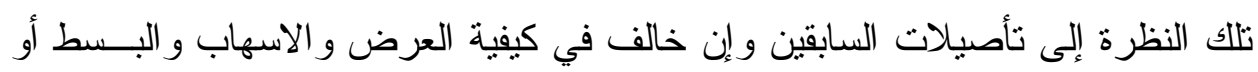

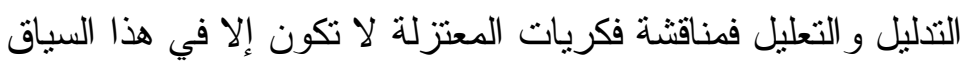

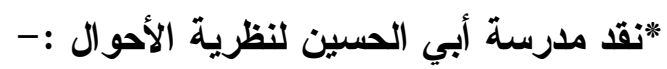

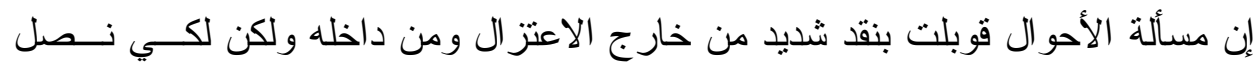

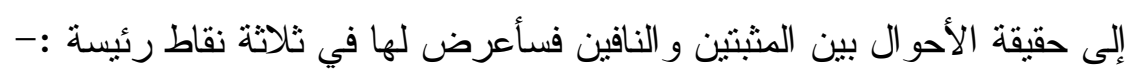

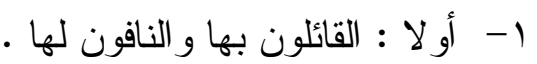

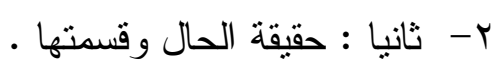

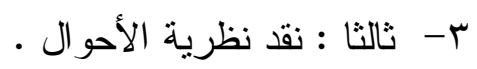

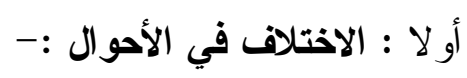

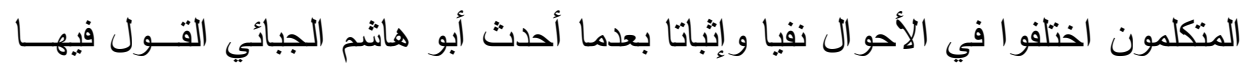

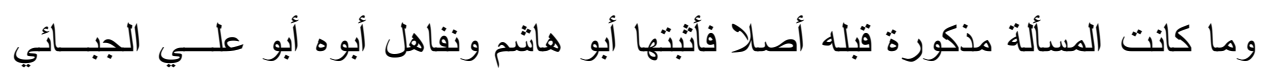

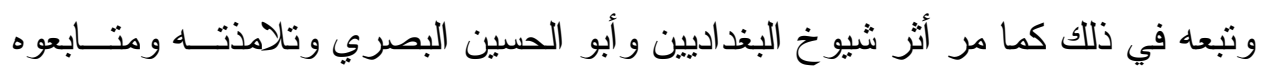

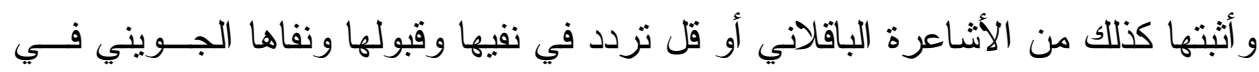

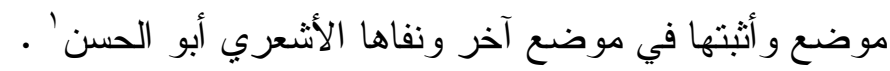

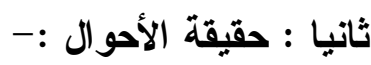

: ليس للحال ابتداء حد حقيقي يذكر حتى نعرفها بحدها وحقيقتها و لا برسم كـذـلك كمـــا

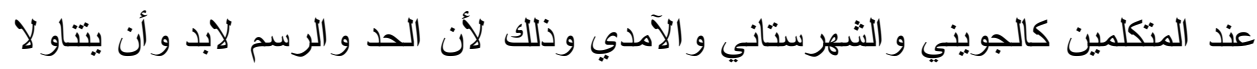

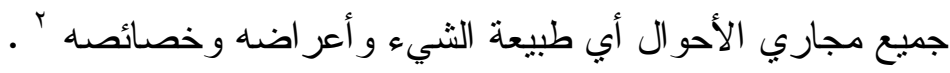

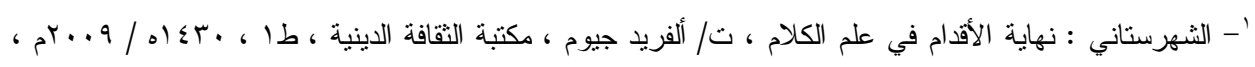

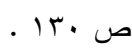

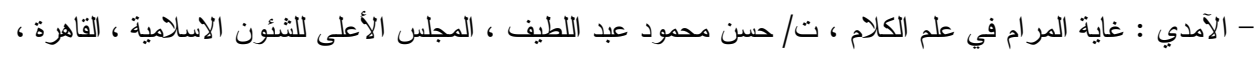

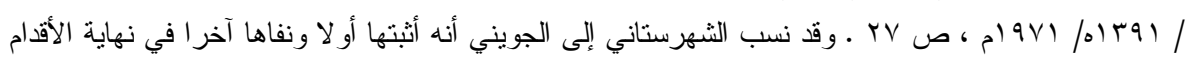

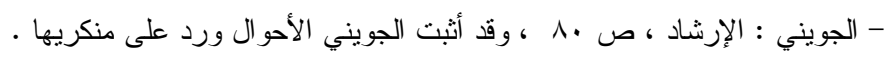

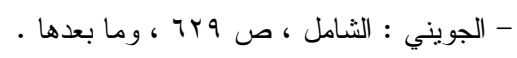

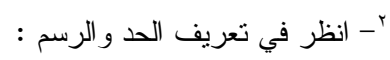

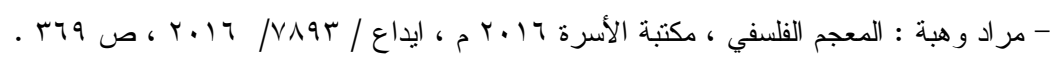


و الا كان أخص منهما و الحد و الرسم يجب أن يكونــا مسـساويين للمحسـدود و لا ألا

أخص منه و لا أعم وذللك يفضي إلى ثثوت الحال للحال من جهة أن الحد لا يتتاولها الا

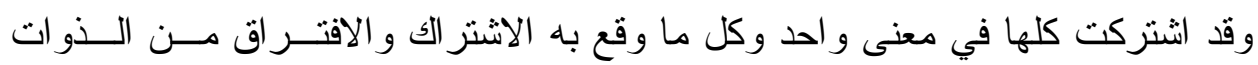

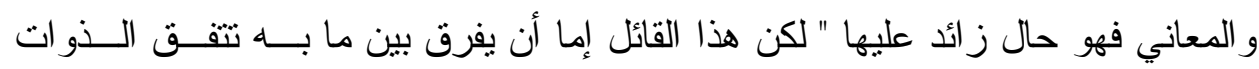

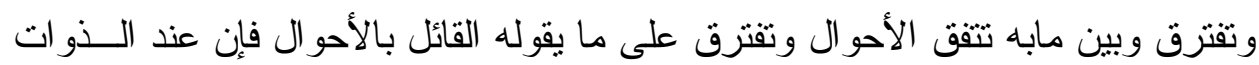

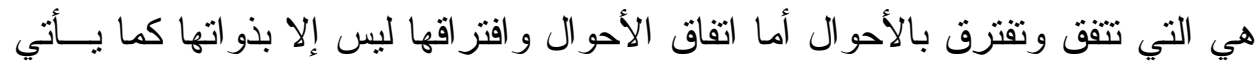

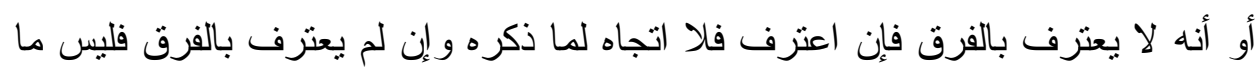

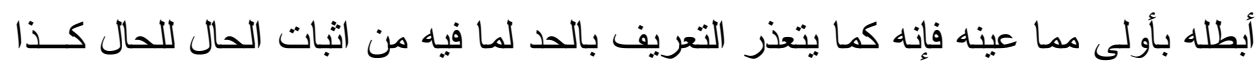

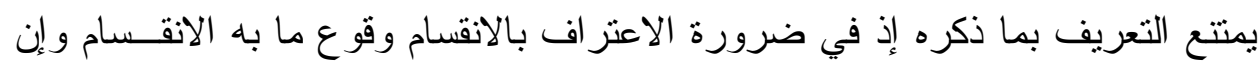

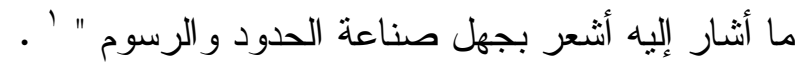

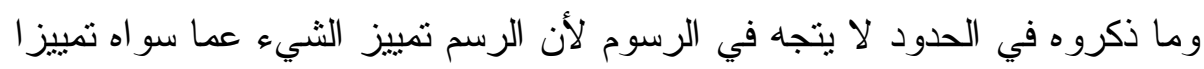

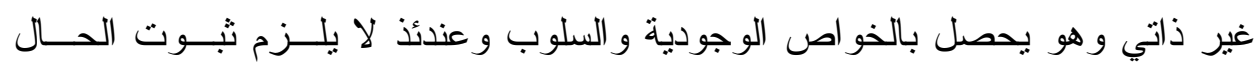

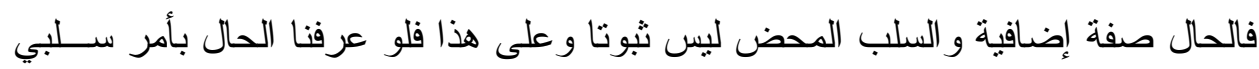

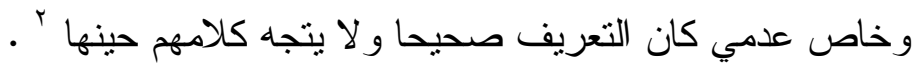
لكن بيان الحال إذا تعذرت الحقيقة والحد و الرسم بأن يكون ذلك اثبات حال للحال فلابد لها من ضابط وحاصر بالقسمة وهي تتقسم إلى ما بعلل و إلى ما لا يعلل . و إذا كانت الحال هي صفة لموجود غير متصفة بالوجود و لا بالعدم على ما ذكره

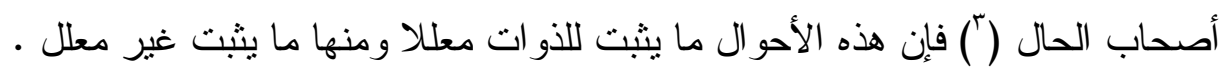

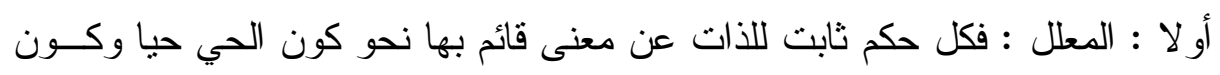

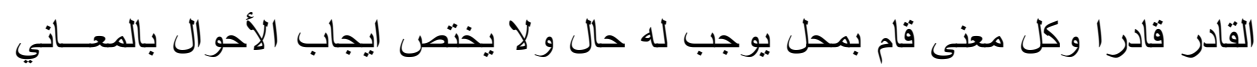

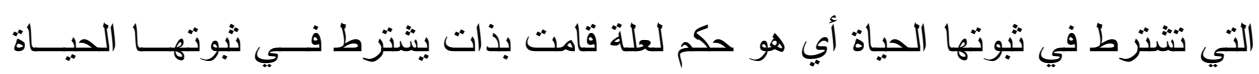

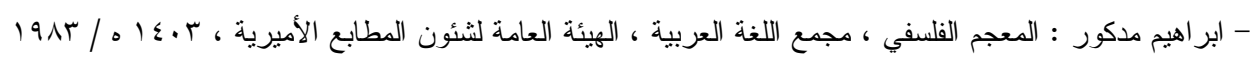

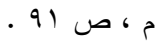

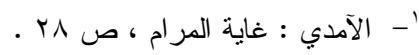

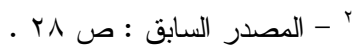

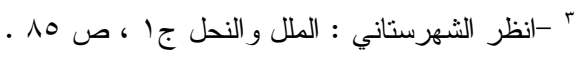
- الجويني : الارشاد ، ص •1 . . 
وكونه حيا عالما يعلل بالحياة و العلم في الثـاهد فتقوم الحياة بمحل وتوجب كون المحـل هل

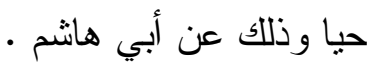

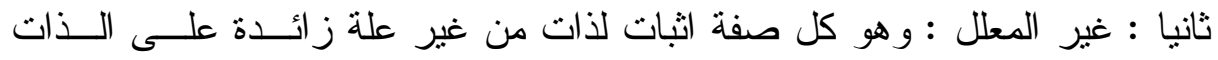

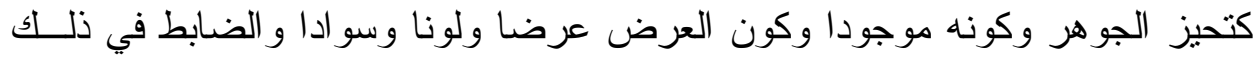

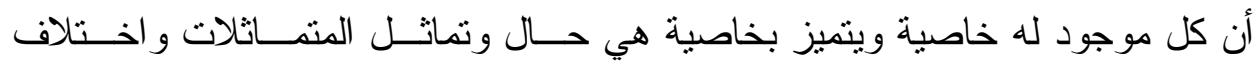

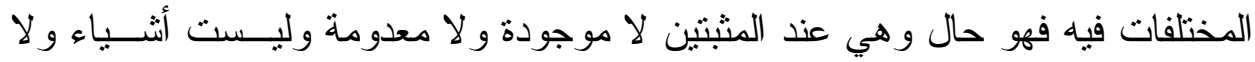

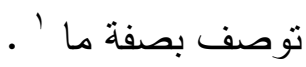
ونظرية الأحو ال هي تسلسل طبيعي لتلك الرؤية التنزيهية لدى أهل الاعتـز ال وإن

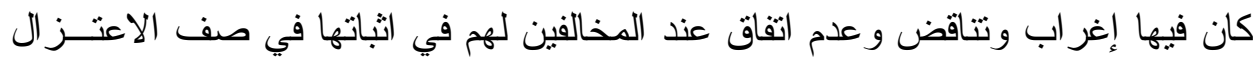

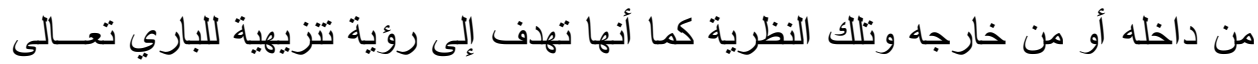
و إن بدت فيها اثنكالات إلا إنها تمنل هروبا من وصمة والنفي الخالص أو التعطيل .

$$
\begin{aligned}
& \text { إذن فهي رؤية تهدف إلى أمرين : - إنهات }
\end{aligned}
$$

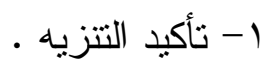

$$
\begin{aligned}
& \text { r- تثبيت الاستحقاق الكربه }
\end{aligned}
$$

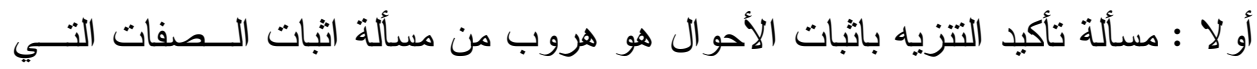

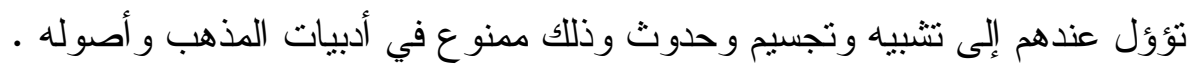

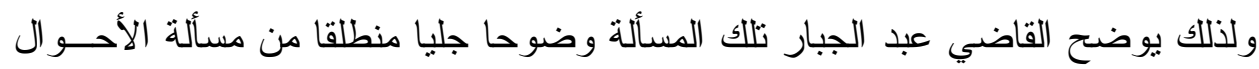
التي تؤكد كما مر أن هذه الأحوال لا نوصف بالوجود وهو المعلوم ولا نوصف بو بالعــدم

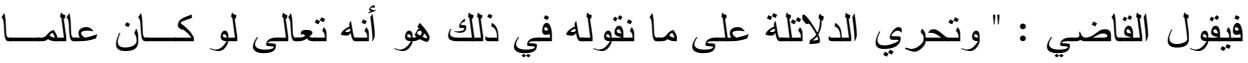

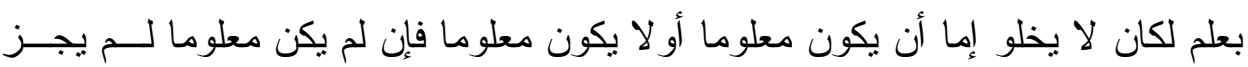

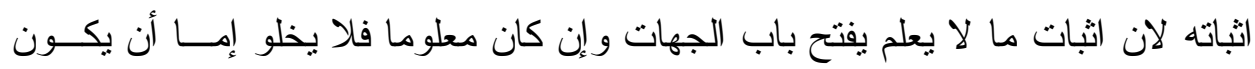

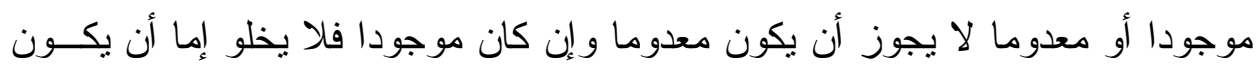

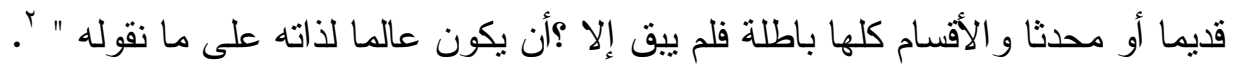

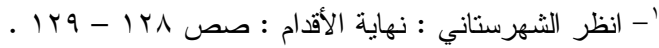

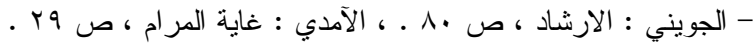

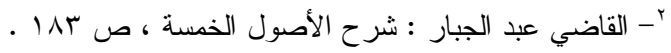




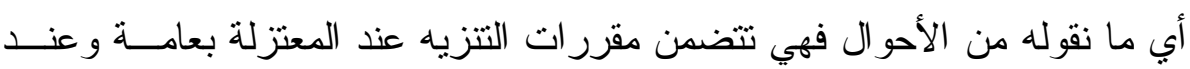

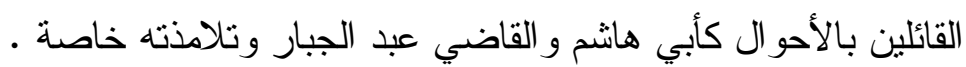

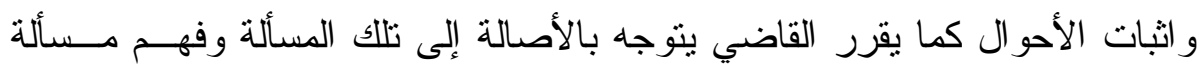

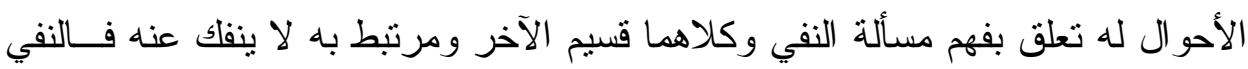

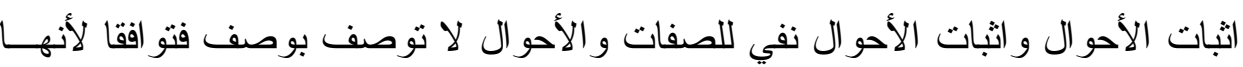

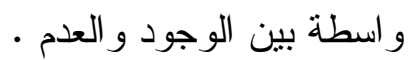

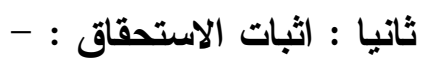

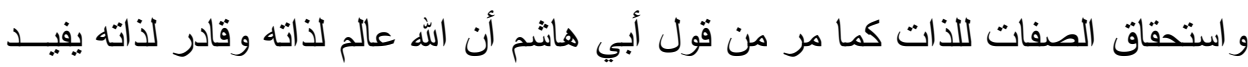

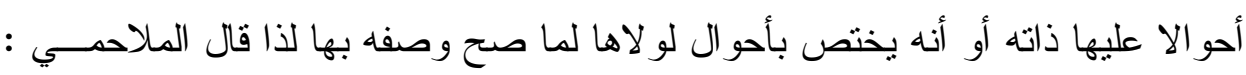

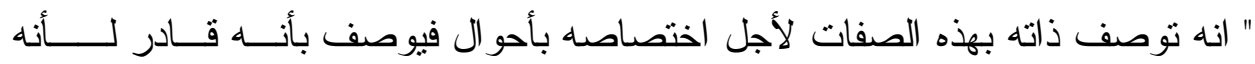

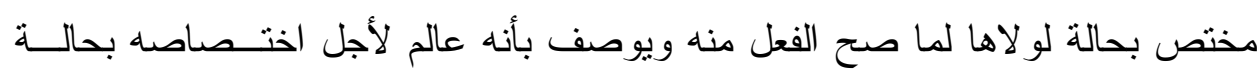

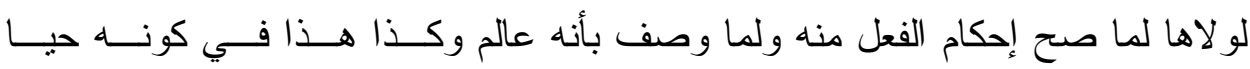

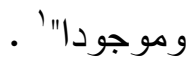

وتأكيدا على تلاك المسألة يرى القاضي عبد الجبار وهو من مثبتي الأحو اتل متابعـا.

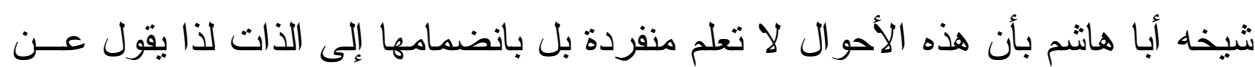
ذللك :

" وليس كذلك الأحو ال فإنها عندنا غير معلومة بانفر ادها و إنما الذات عليها تعلم "' .

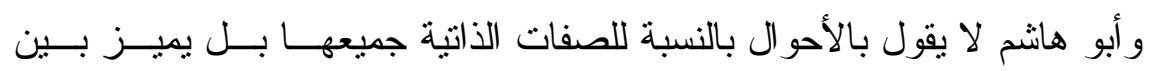

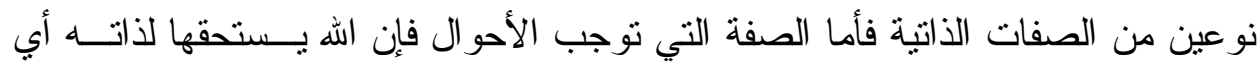

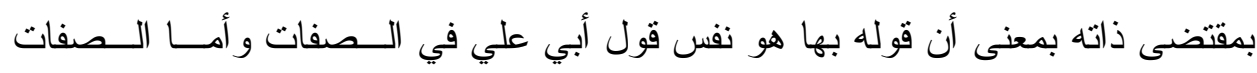

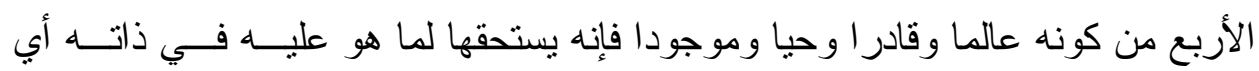

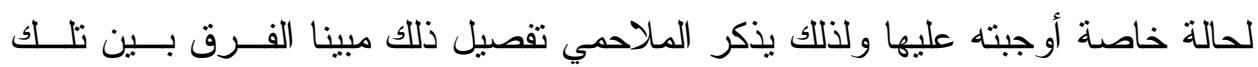
الحالة مع الصفات الذاتية ومع انفر ادها. فيقول : " اعلم أن الثيخ أبا هاشم و أصحابه هم المثبتون للأحو ال فيثبتــون لله

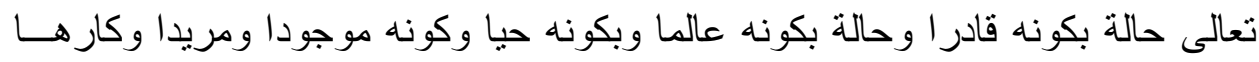


ويثتبتون منل هذه الأحوال في الثـاهد للحي القادر العالم المريد الكاره منا ويثتبــون لـــه

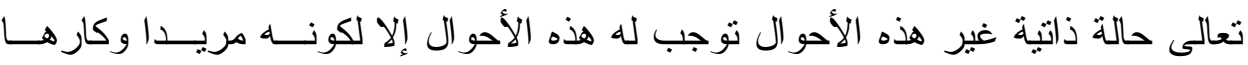

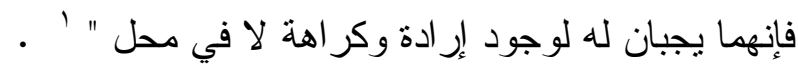

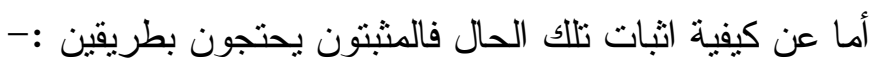

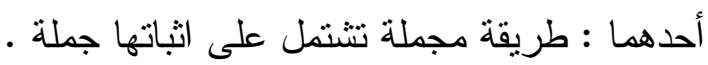

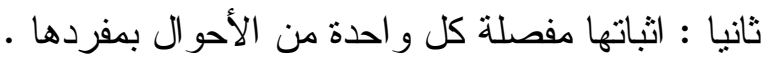

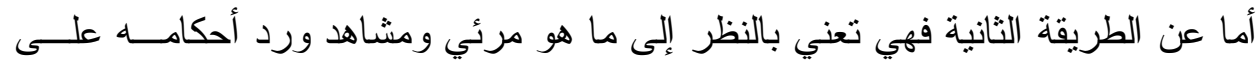

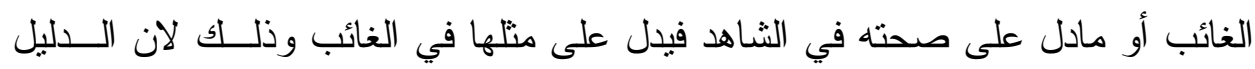

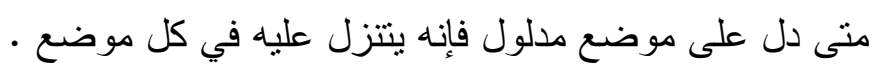

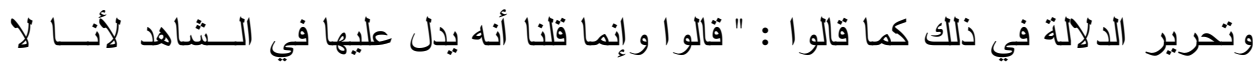

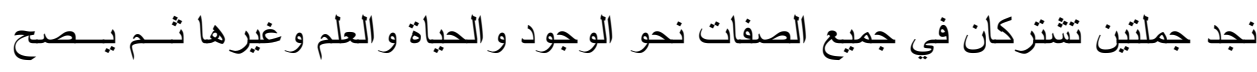

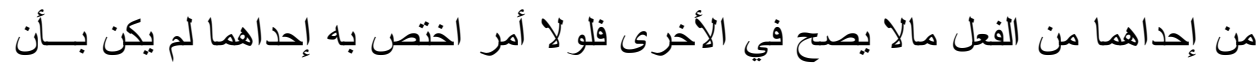

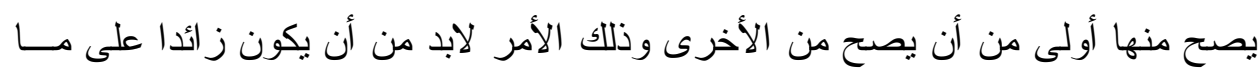

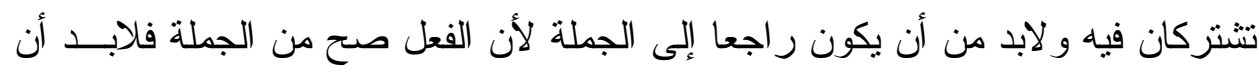

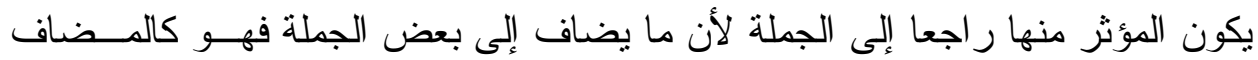

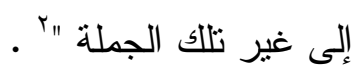

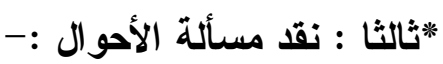

لقد لاقت مسألة الأحو ال البهشمية نقدا شديدا بين خصومها أو من داخل صــفوفها

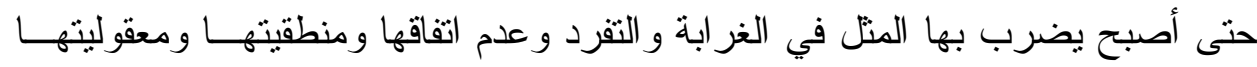

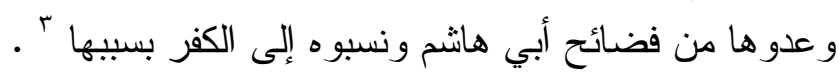

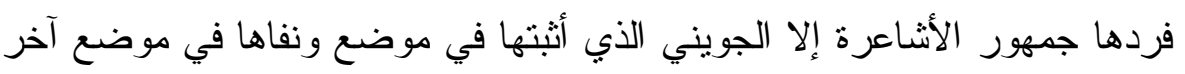

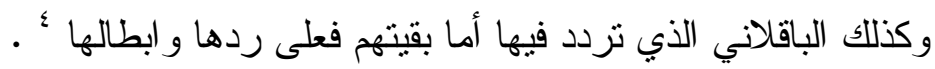

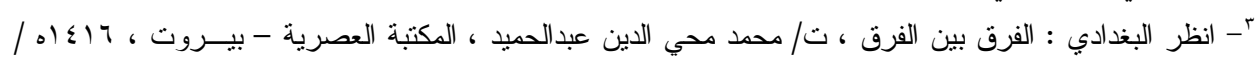

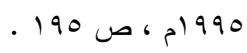

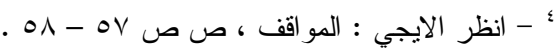




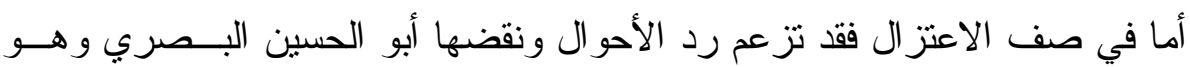

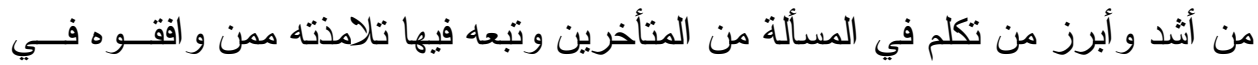
ردها وقد كان لأبي الحسين البصري أثز كبير في صياغات جديدة لمذهب الاعتـز ال لا لاني في هذه القضية وحدها بل في المذهب في مجمله وكما بينا من قبل إن كتب الملاحمـي لئي

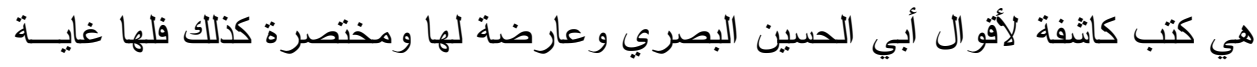

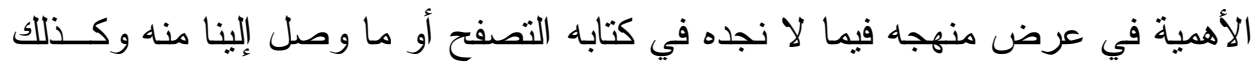

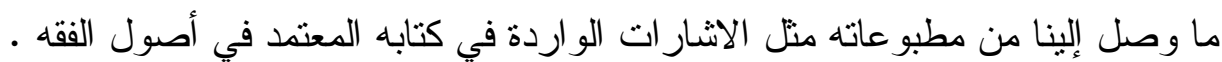
فأبو الحسين البصري يرفض الأحو ال وتبعه في ذللك مدرسته من تلامذتــهـ ولكـيـي نتوصل إلى فهم مذهب أبي الحسين البصري في ذللك :-

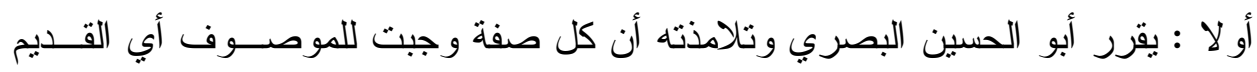

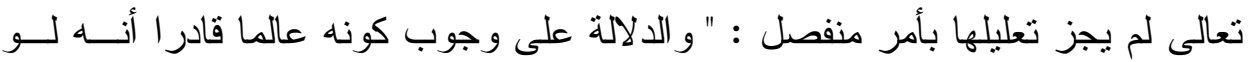
جاز ذلك ولم يجب لاستحق ذللك لمعنى محدث وذللك فاسد ، و الدالالة على أن الصفة إذا عاد

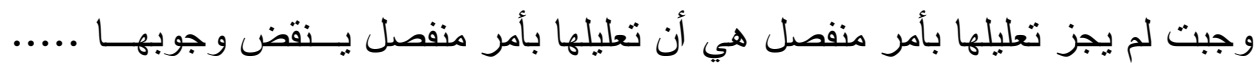

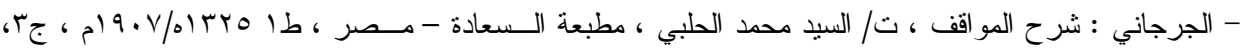

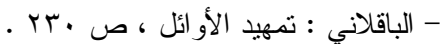

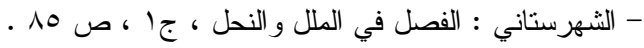

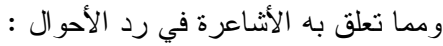
أو لا : الأحو ال إما أن تكون موجودة أو لا تكون وليس بين النفي و الآثات و واسطة فإذا كانت موجودة فليست حالا لأن الأ

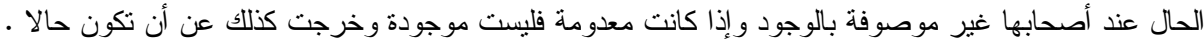

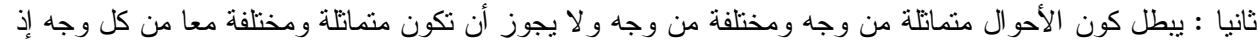

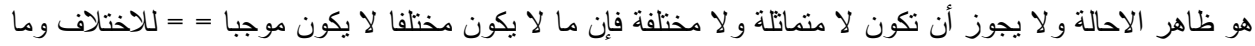

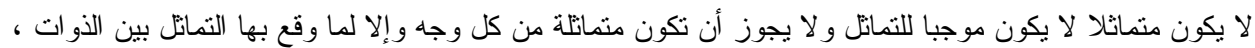

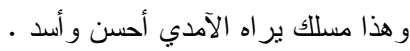

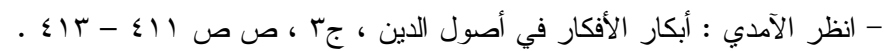

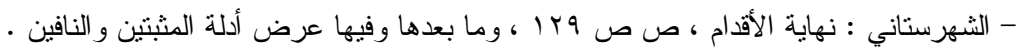
'- أبو الحسين البصري : نصفح الأدلة ، ص 1 ـ . 
ثم ينطلق أبو الحسين البصري في بيان مذهبه الذي يخالف به طريقة القاضي عبد

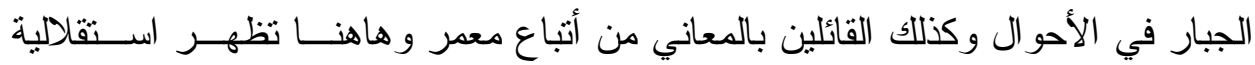

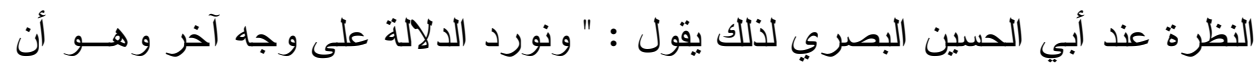
وجوب كونه عزوجل عالما قادر ا يقتضي الصفة الذاتية وما اقتضى صفة فهو حكمهــا

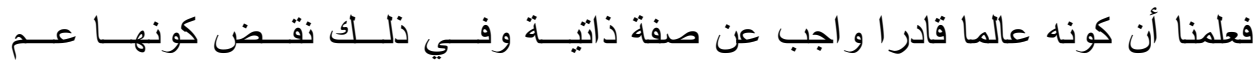
• ' معنى

وفي ذلك ينقض أبو الحسين القول بالمعاني والأحوال وحاصل ما ذهب إليه أبو الحسين

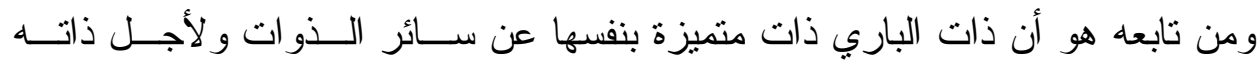

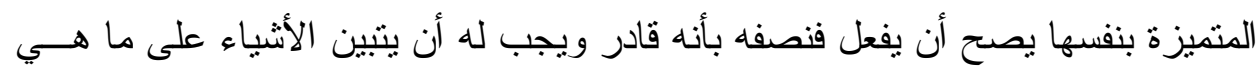
عليه فنصفه بأنه عالم ويجب له أن لا يستحيل أن يعلم ويقدر فنصفه بأنه حي و لا حاجة

في اثبات أمر زائد على ذاته لنتبت له له هذه الأحكام ' .

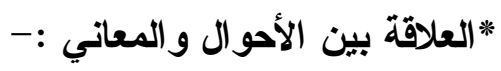

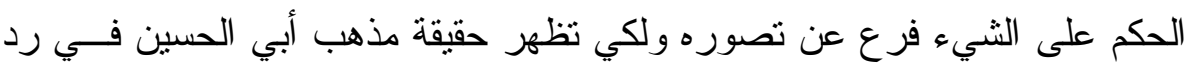

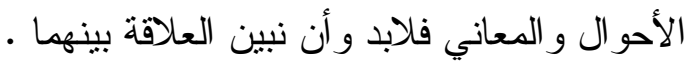

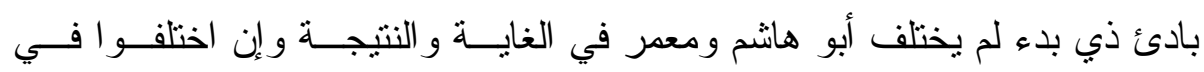

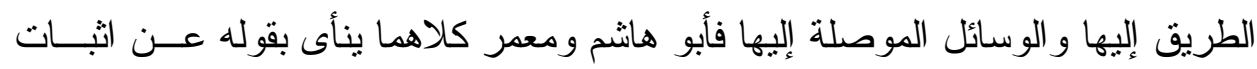

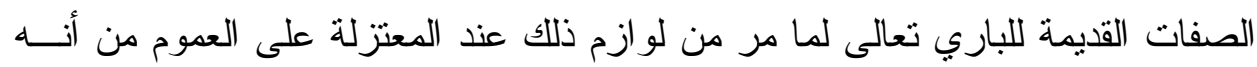
يودي بالقول عندهم إلى اثبات ثان للقديم و آلهة متعددة وتلاك النظرة المستقرة في أدبيات

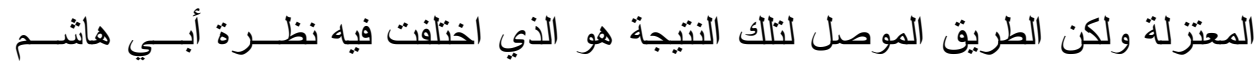

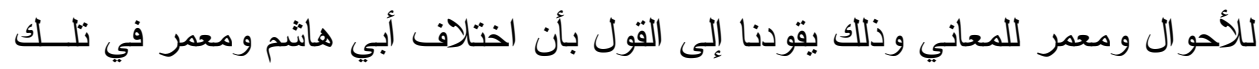
المسألة إنما هو خلاف في التنزيل وليس خلافا في التأصيل .

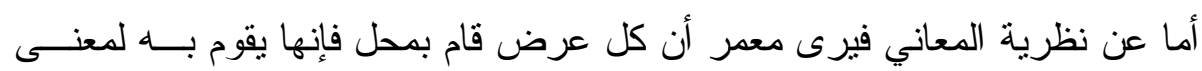

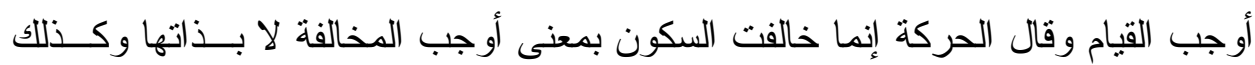

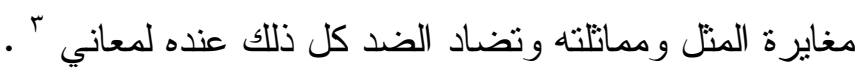

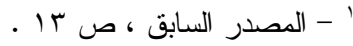

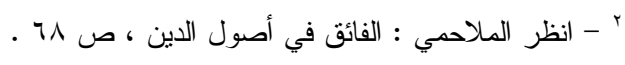

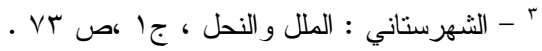




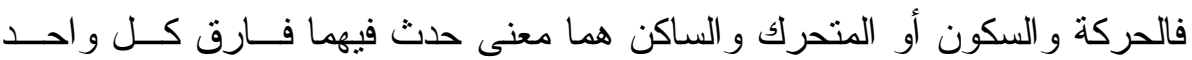

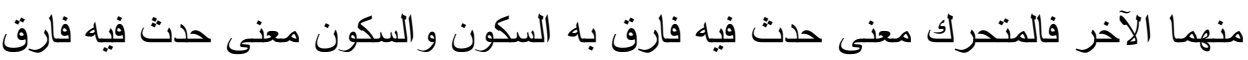

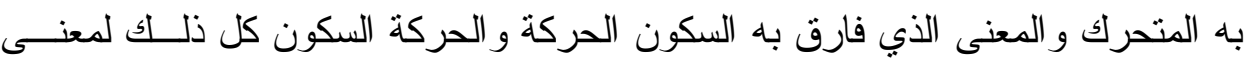

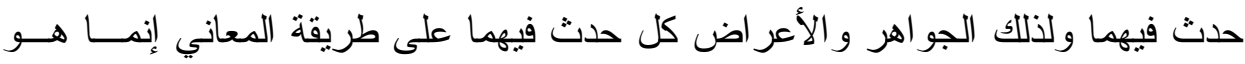

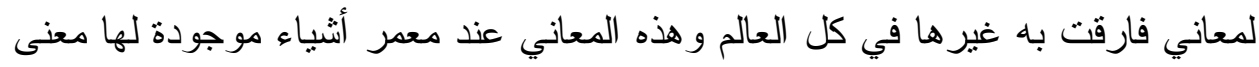

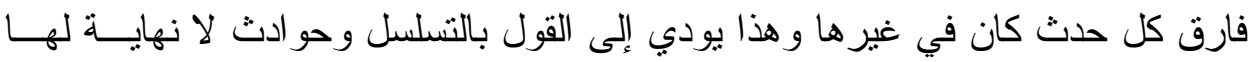
وذللك مقتضى ما حكاه عنه الكعبي في مقالاته حيث حكي عنه : " أن الحركة عنده إنما

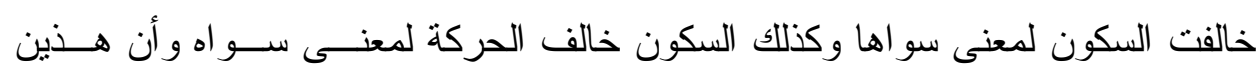

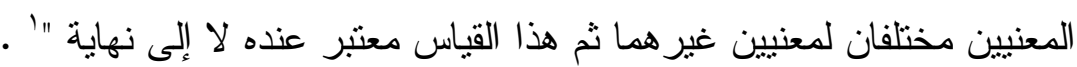
وليس أحد أقدر على شرح طريقة المعاني و بيان حقيقتها من معتزلي كالخياط الذي في هئي

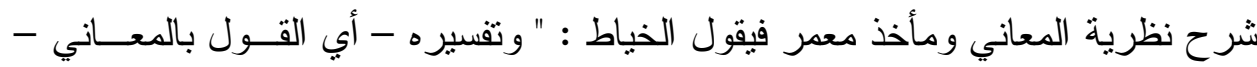

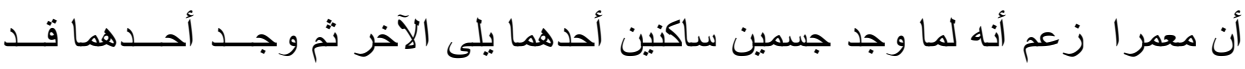

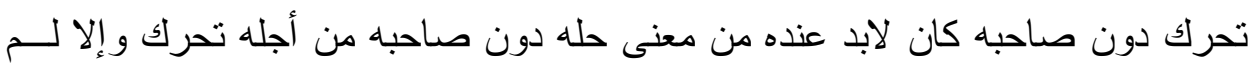

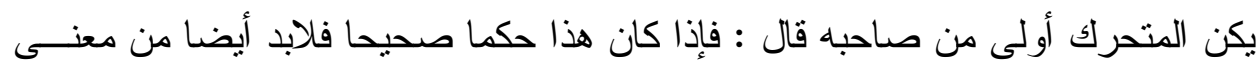
حدث له حلت من أجله الحركة في أحدهما دون صاحبه و إلا لم يكن حلولها في أحدهما

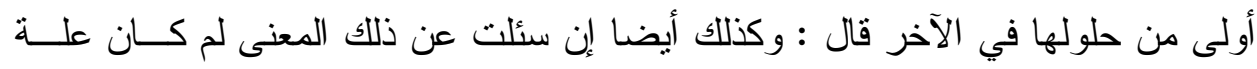
لحلول الحركة في أحدهما دون صاحبه قلت : لمعنى آخر فال : وكذلك أيضا إن سئلت

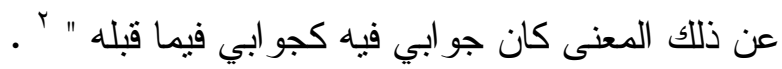

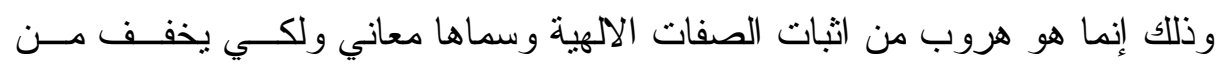

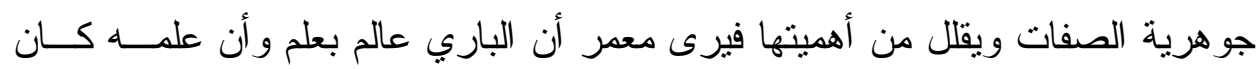

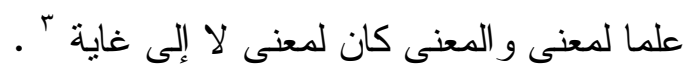

\footnotetext{
- البغدادي : الفرق بين الفرق ، ص ror ـ .

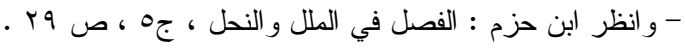
r
}

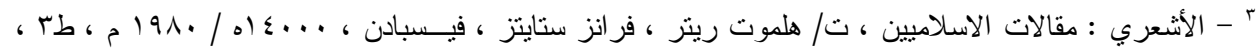


إذن معدر بطريقته في المعاني يريد اثبات ذات قديمة لبس فيها تكثر البتة فيبعد بطريقة

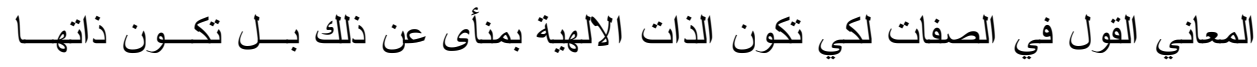

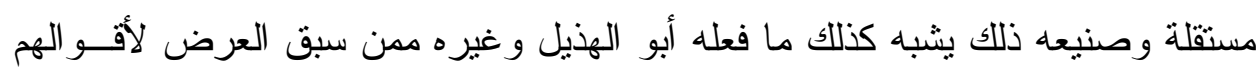

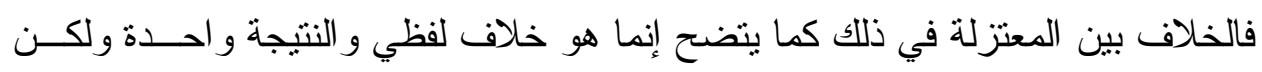

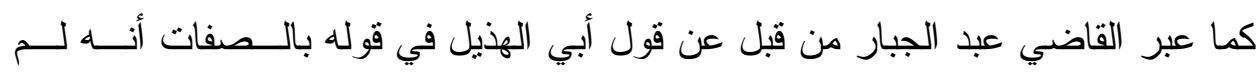

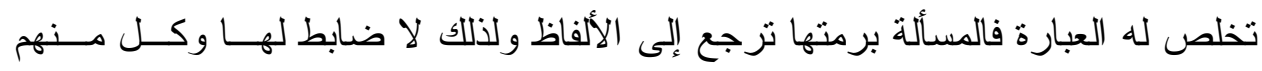

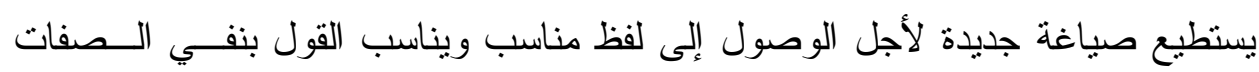
وعد التكثر في الذات و إذا كانت المسألة عند المعتزلة لفظية وكما تهرب معمر من اثبات صفات قديمــة كذلك تهرب أبو هاشم بالأحو ال عن القول بقدم الصفات وقدم طريقته في الأحو ال بــأن

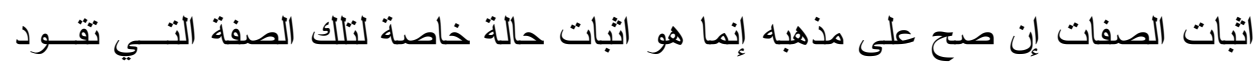

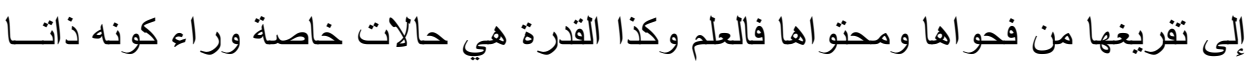

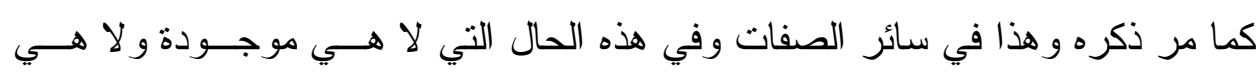

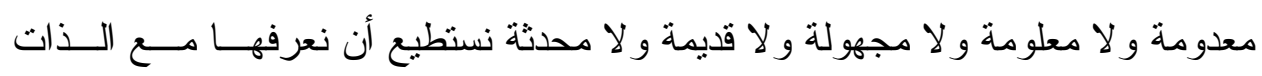

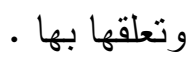

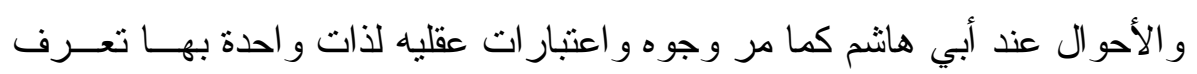

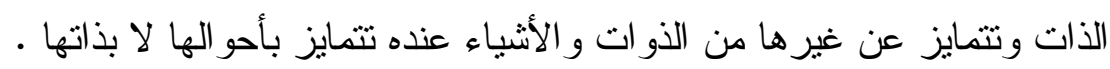

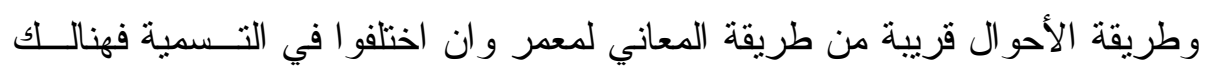
تعلق بين القول بالأحول وكذلك المعاني ' ل و إذا فههنا ذلك التعلق بين الأحو ال و المعاني فههنا وجه رد رد أبي الحسين البــصري

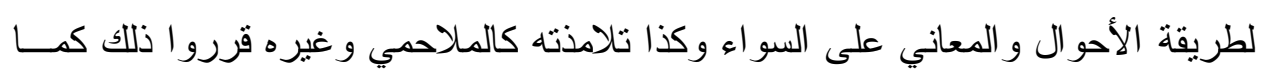

$$
\begin{aligned}
& \text { يتضح بعد ذلك . }
\end{aligned}
$$

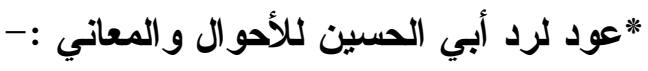

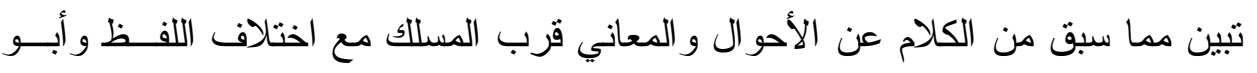

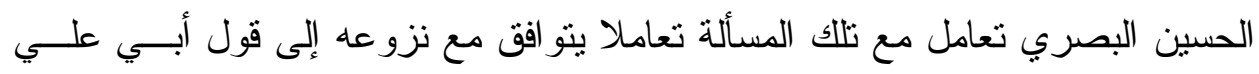

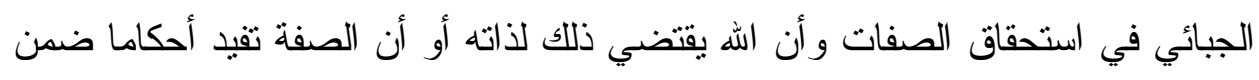

' - انظر في العلاقة بين الأحوال و المعاني هاري ـ أ. ولفسون : فلسفة الدتكلمين ، جا ، ص سمب . 
العلم بذاته كما مر ذكره وكذللك قعد أبو الحسين لذلك وقد أكد على ذلك بقولــهـ أن مـــا

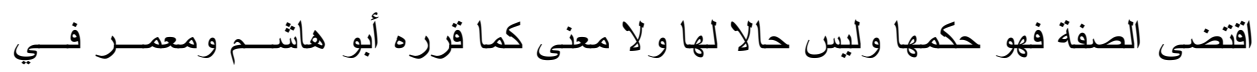

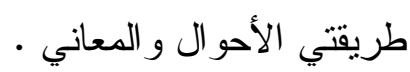
و الخلاف بين أبي الحسين البصري وأبي هاشم و أحواله ومعمر وطريقته في المعاني

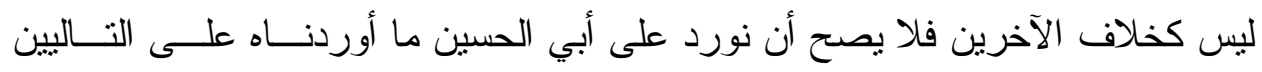

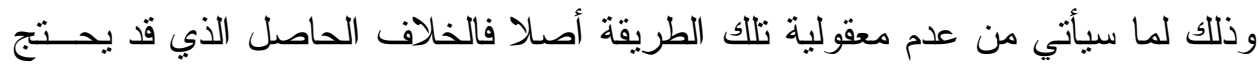

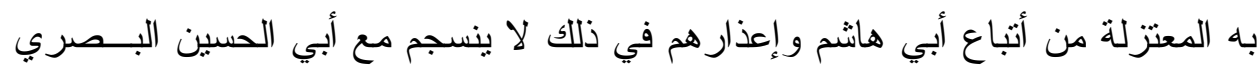

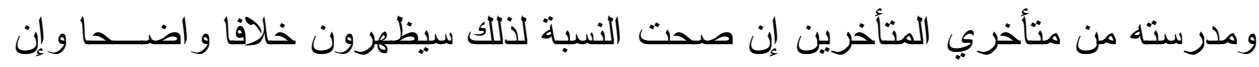

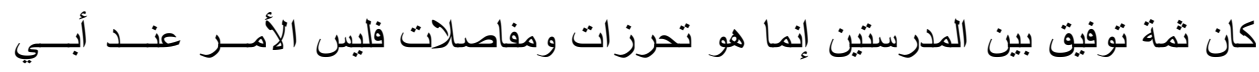

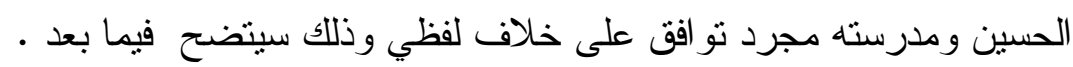

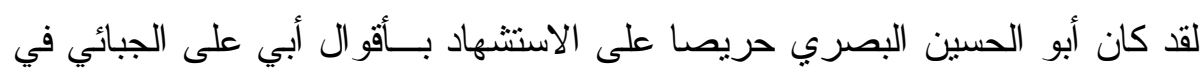

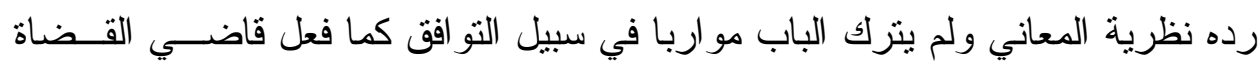

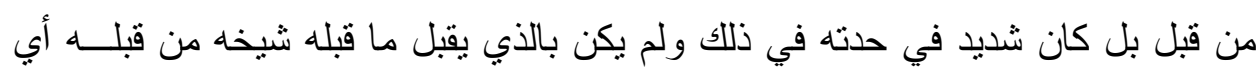

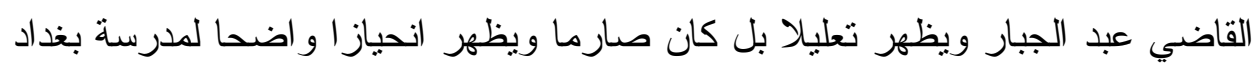

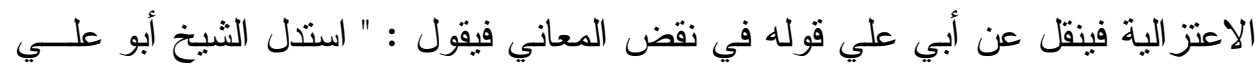

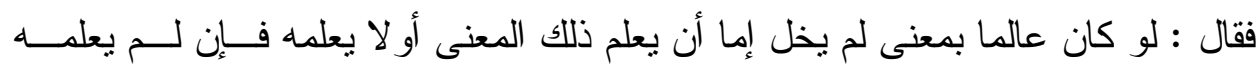

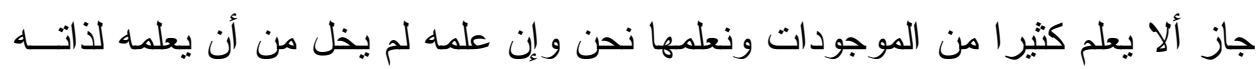

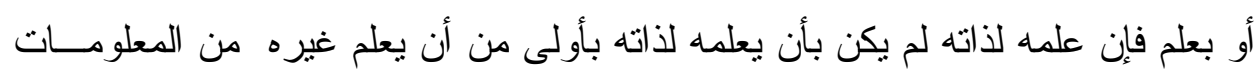

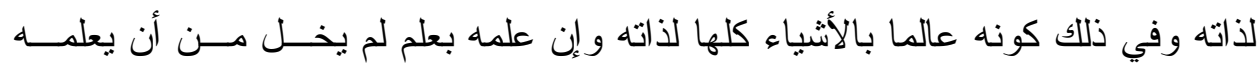

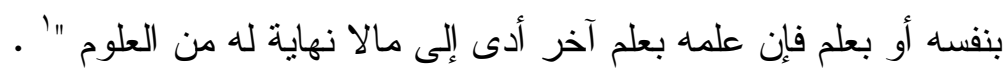

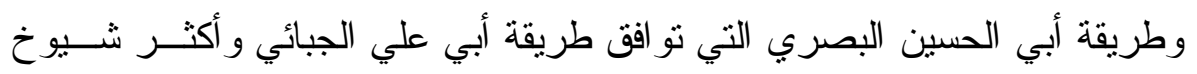

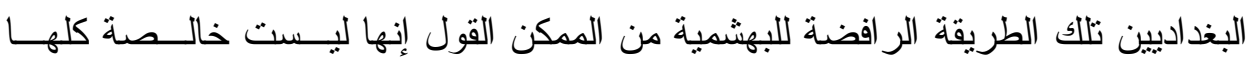

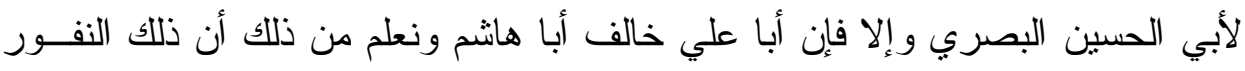

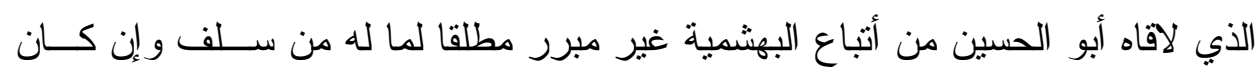

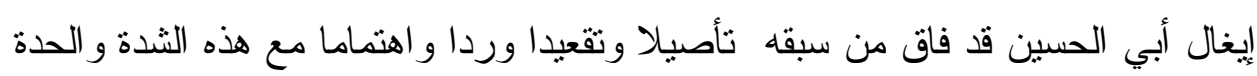
التي كانت عنده . - التين

| - أبو الحسين البصري : تصفح الأدلة ، ص 17 . 
( استحقاق الأت للصفات : *

في سياق رد أبي الحسين البصري القول بالمعنى وأنه لا طريق لإثباته هو فساد ذلك

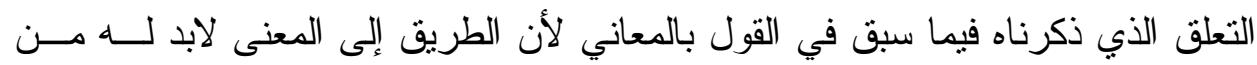

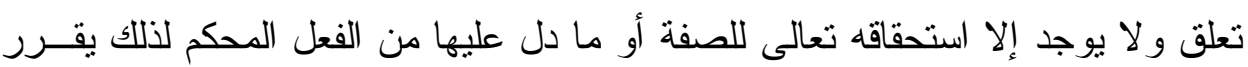

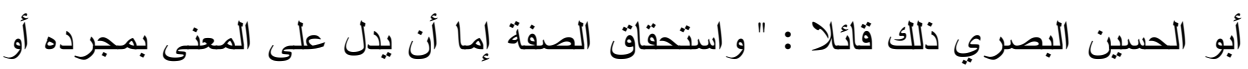

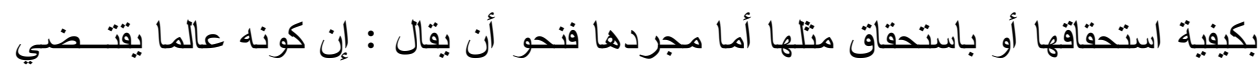

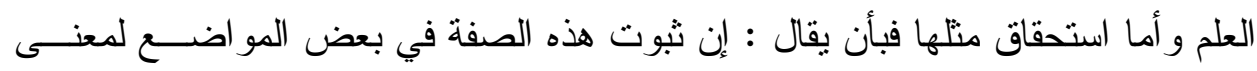

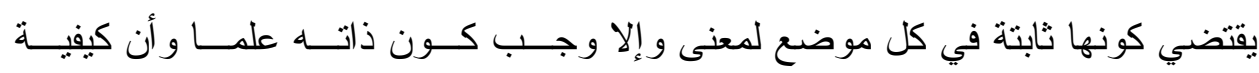

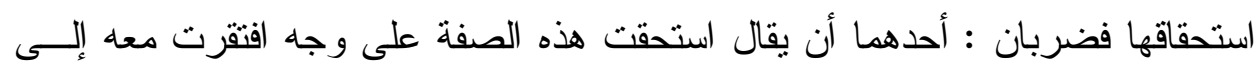

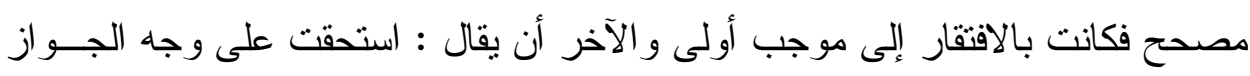

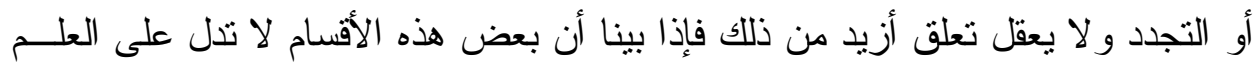

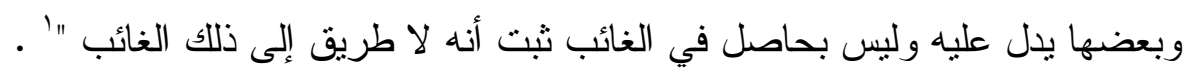

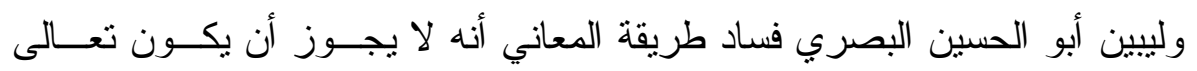

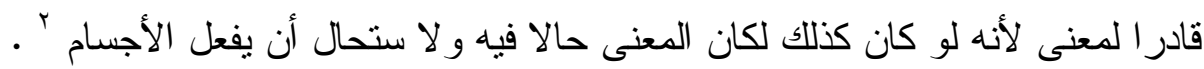

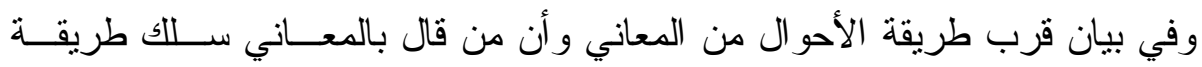

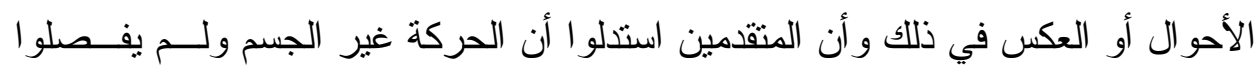

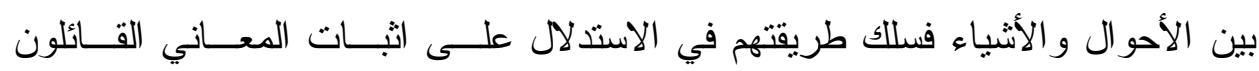

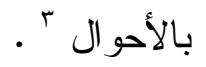

ومما توجه للقول بالأحو ال و المعاني من نقد كان قولهم بالتسلسل من اثبات أحوال لا

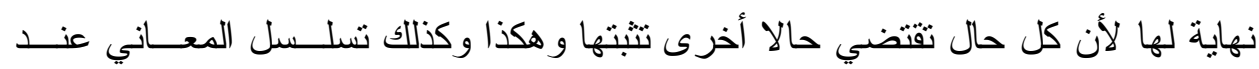
معر

وفي ذلك يقول أبو الحسين البصري : " لو علم عزو جل بمعنى لم يخل من أن يكـون

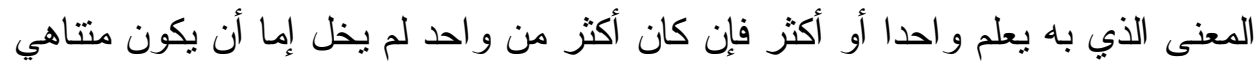

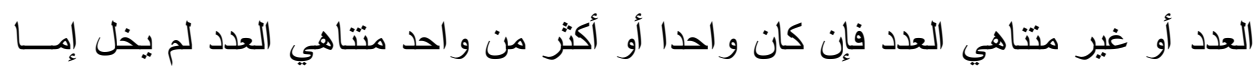

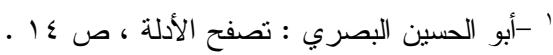

$$
\begin{aligned}
& \text { r }
\end{aligned}
$$

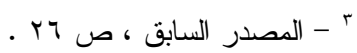


أن يعلم بذلك كل المعلومات أو لا يعلم كلها وكل هذه الأقسام باطل فما أدى إليها باطـلـلـ

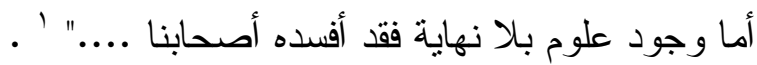

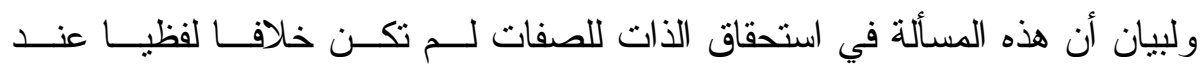

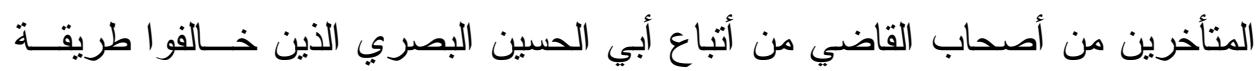

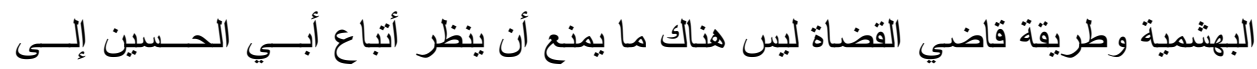

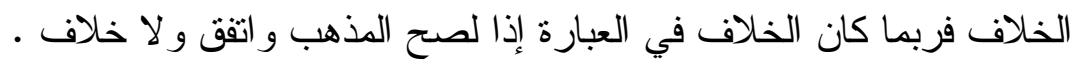

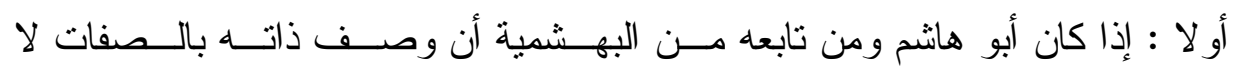

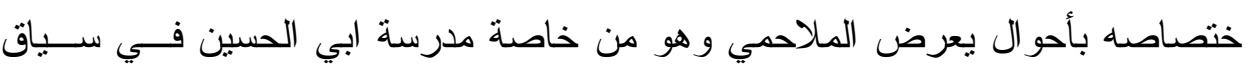

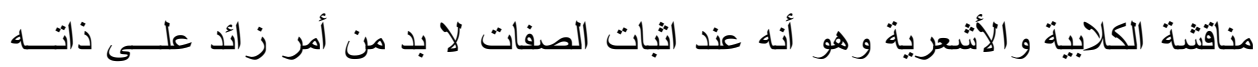

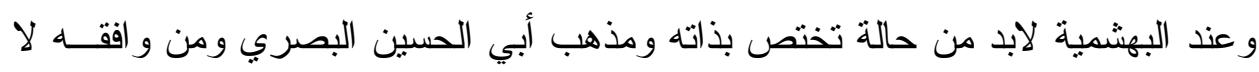

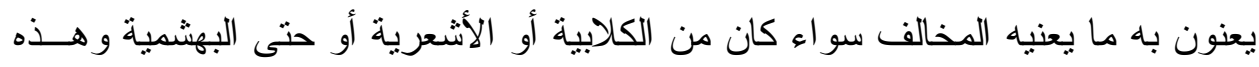

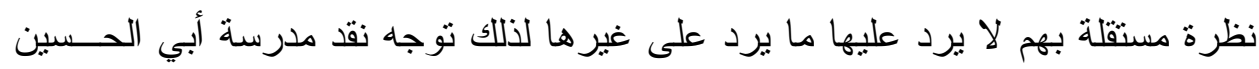

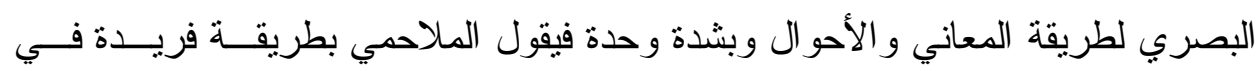

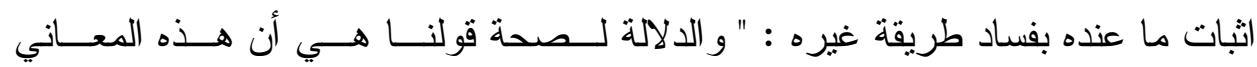

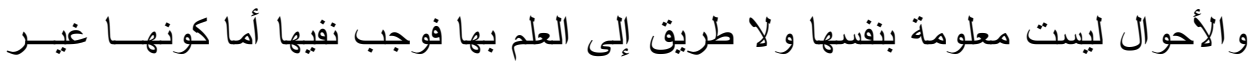

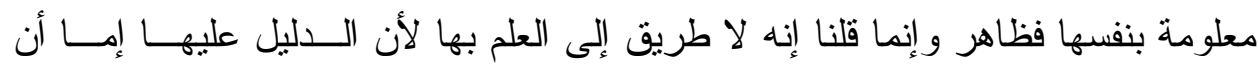

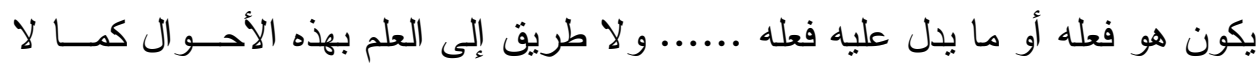

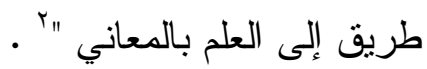

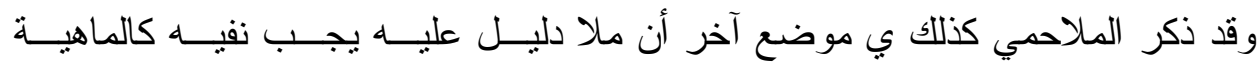

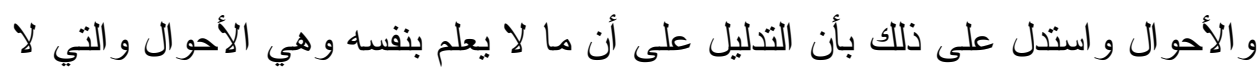

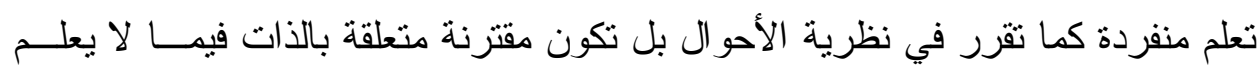

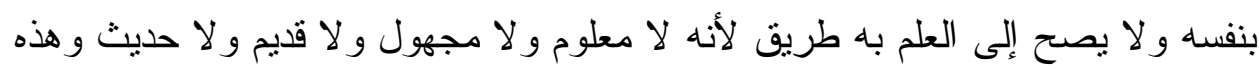

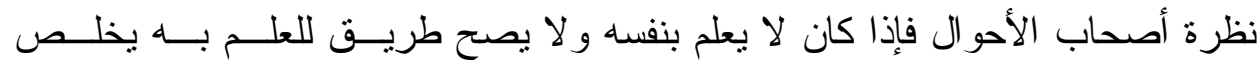

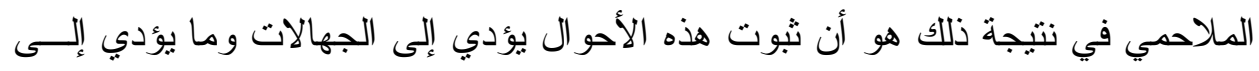

$$
\begin{aligned}
& \text { ' - أبو الحسين البصري : تصفح الأدلة ، ص V؟ . }
\end{aligned}
$$

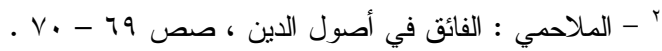




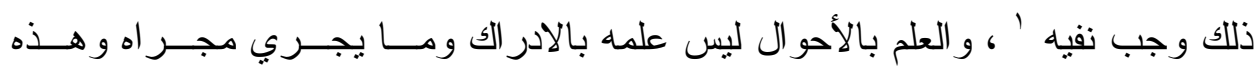

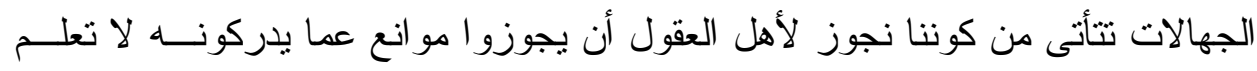

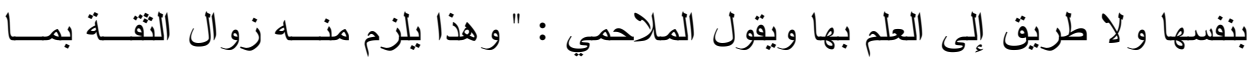

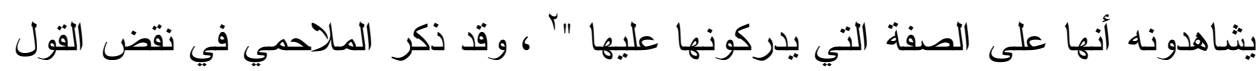

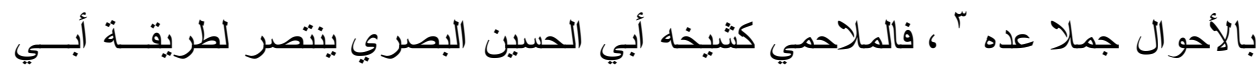

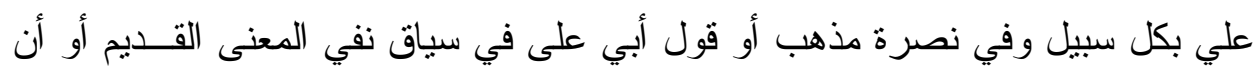

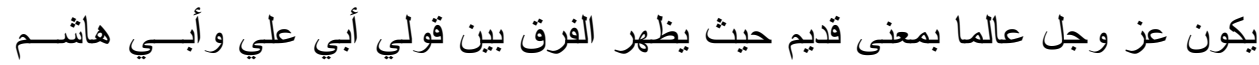

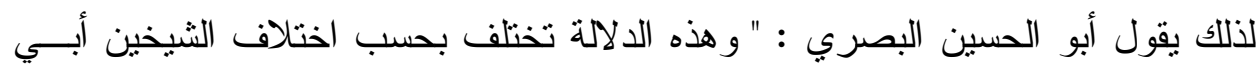

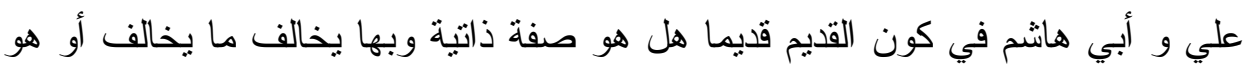

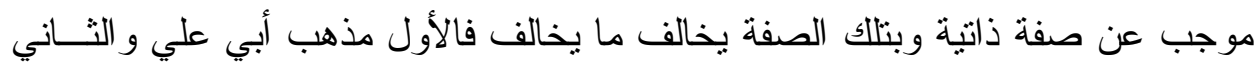
مذهب أبي هاثم ونرتيب الدلالة على مذهب أبي علي يكون من وجهين : أحدهما هكذا

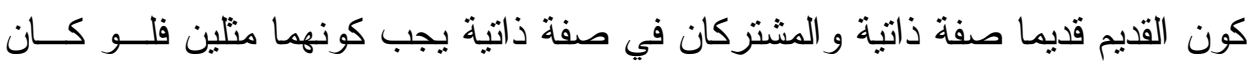

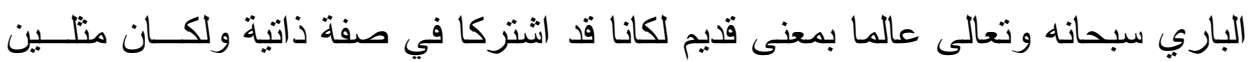
بك ن......

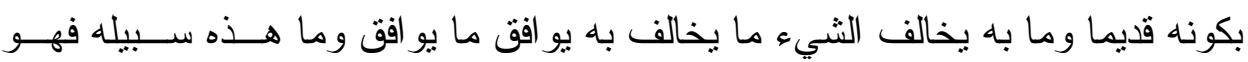

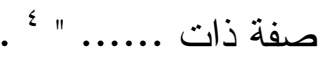
وبذلك يتبين مخالفة أبي الحسين البصري وتلاميذه لمسألة الأحو ال و المعـاني وعــدم

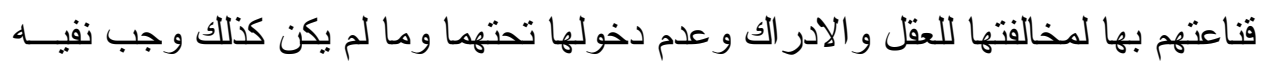
وكذلك كان نقد أبو الحسين وتلامذته لمسألة الأحو ال .

$$
\begin{aligned}
& \text { - الملاحمي : المعتمد في أصول الدين ، ص r بر . }
\end{aligned}
$$

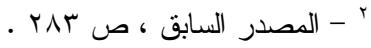

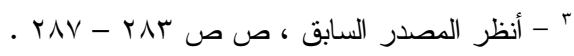

$$
\begin{aligned}
& \text { ؛ - أبو الحسين البصري : تصفح الأدلة ، ص } 07 \text { ه ـ . }
\end{aligned}
$$

